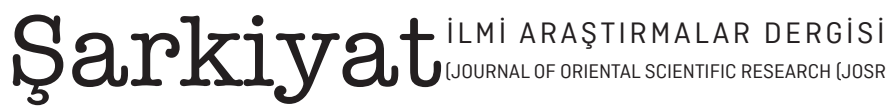 \\ Cilt/Volume: 13, Sayı/Issue: 3 (Aralık/December 2021]
}

\section{AHLAK-BENLIK BÜTÜNLÜĞÜ: AHLAKI KIMLIK}

\begin{abstract}
Eyüp AKTÜRK
Doç. Dr. Van Yüzüncü Yıl Üniversitesi, Eğitim Fakültesi,

eyupakturk@yyu.edu.tr. https://orcid.org/0000-0001-6713-3199
\end{abstract}

\author{
Article Types / Makale Türü \\ Research Article / Araştırma Makalesi
}

Received / Makale Geliş Tarihi

27/09/2021

Accepted / Kabul Tarihi

$13 / 12 / 2021$

https://doi.org/10.26791/sarkiat.1001576 


\section{AHLAK-BENLIK BÜTÜNLÜĞÜ: AHLAKI KIMLIK}

\section{öz}

Ahlaki eylemi/davranışı tam olarak motive eden şey nedir? Ahlaki motivasyona ilişkin teori ve araştırmalar son dönemlerde ahlaki muhakemenin statüsüne odaklanmıştır. Ancak son zamanlarda, ahlaki motivasyonun önemli bir kaynağı olarak kimlik de ön plana çıkmaktadır. Bir birey kendi benlik duygusunu ahlaki kaygılar ve değerler etrafinda inşa ettiği sürece ahlaki bir kimliğe sahip olur. Burada ahlaki kaygılar ile kişisel kaygılar birleştiği/bütünleştiği için ahlaki kimlik gerçek benlik olur; ve bireyin eylemlerini yönlendiren en derin ilke olarak deneyimlenir. Nitekim ahlaki olgunluk sadece doğrunun (veya yanlışın) bilgisine sahip olmayı değil, aynı zamanda bu doğru bilgiye uygun hareket etmeyi de gerektirmektedir. Burada başarılması gereken şey hem doğru düşünmek hem de doğru davranmaktır. Buradaki temel iddia ahlaki eylemlerin hem ahlaki yargının hem de ahlaki kimliğin sonucu olduğu ve ahlaki kimliğin ahlaki yargı ile ahlaki eylem arasındaki boşluğu doldurduğudur. Kimliğin ahlaki işleyişte önemli bir rol oynayabileceğine ilişkin bu düşünce ahlaki kimliğe yönelik çalışmalara ilgiyi de artırmıştır. $\mathrm{Bu}$ makale, ahlaki kimlik ile ahlaki eylem arasındaki ilişkiye yönelik bir araştırmayı hedeflemektedir.

Anahtar Kelimeler: Ahlaki kimlik, ahlaki motivasyon, ahlaki eylem, ahlaki gelişim.

\section{MORAL-SELF INTEGRITY: MORAL IDENTITY}

\section{ABSTRACT}

What exactly motivates moral action? Theory and research on moral motivation have recently focused on the status of moral reasoning. Recently, however, identity has come to the fore as an important source of moral motivation. An individual has a moral identity as long as he builds his sense of self around moral concerns and values. Here, moral identity becomes the real self, as moral concerns and personal concerns merge/integrate; and experienced as the deepest principle guiding the actions of the individual. As a matter of fact, moral maturity requires not only having the knowledge of right (or wrong), but also acting in accordance with this right knowledge. What needs to be accomplished here is to think right and act right. The main argument here is that moral actions are the result of both moral judgment and moral identity, and that moral identity bridges the gap between moral judgment and moral action. This idea that identity can play an important role in moral functioning has also increased the interest in studies on moral identity. This article aims to investigate the relationship between moral identity and moral behavior.

Keywords: Moral identity, moral motivation, moral action, moral development, 


\section{GíRiş}

Ahlakı karakterize etme ve ahlaki bir yaşamı tanımlama çabalarının çok köklü bir geçmişi vardır. Birçok filozof/düşünür insan eylemlerinin ne tür etik standartlara göre düzenlenmesi gerektiğini ortaya koyma çalışmış ve ahlaki bir yaşam sürdürmenin koşullarını sıralamıştır. Hiç kuşkusuz, burada ahlaki ilkelerin var olduğuna ve bu ilkelerin eyleme rehberlik etmesi gerektiğine yönelik bir düşünce söz konusudur. Kişinin belirli ahlaki amaçlara ve ilkelere olan sarsılmaz bağl1lığı sonucunda ancak 'iyi' bir yaşam mümkün olabilir. Pekâlâ, ömür boyu süren ahlaki bağlılığın temelinde ne vardır? Bu nasıl mümkün olacaktır?

Ahlaki olgunluk sadece doğrunun (veya yanlışın) bilgisine sahip olmayı değil, aynı zamanda bu doğru bilgiye uygun hareket etmeyi de gerektirmektedir. Burada başarılması gereken şey hem doğru düşünmek hem de doğru davranmaktır. Sokrates ve Platon gibi filozoflar 'iyiyi bilmek, iyiyi yapmaktır; iyiyi yapmak için iyiyi bilmek gerekir' diye düşündüler. Sokrates açısından, insani gelişimin en yüksek aşaması ile 'iyi'nin bilgisini bilmek arasında bir bağ söz konusudur. Ona göre, yaşama değer tek hayat 'iyi' bir hayattır ve iyi bir hayat da ancak 'iyi’ ve 'kötü'nün bilgisini bilmekle yaşanabilir. Sokrates açısından ahlaki bir yaşam için ahlaki bilgi hem gerekli hem de zorunludur. Kişiler yapmaları gereken şeyin ne olduğu bildikleri zaman rasyonel olarak gerekenden başka bir şey yapamazlar(d1). Bu çerçeveden bakıldığında, yanlışlığın tek nedeni cehalet olarak ifade edilmektedir. ${ }^{1}$ Geçtiğimiz yarım yüzyılda, ahlak üzerine yapılan çoğu çalışma, özellikle Kohlberg'in ahlaki muhakemeyi (moral reosoning) vurgulayan bilişsel gelişim teorisi bu bakış açısıyla çerçevelenmiştir. Platon gibi Kohlberg de (en azından başlangıçta) olgun (mature) bir ahlaki muhakemenin ahlaki eylemi motive edeceğine inanıyordu. Ahlaki muhakeme geliştikçe, ahlaki durumlarda hüküm vermesi gereken bireyler, ahlaki ilkeleri kullanmaya daha yatkın hale gelecektir. Ahlaki muhakemenin daha yüksek aşamalarında ise ahlaki ilkeler ve bunların evrensel doğası daha belirgin olacaktır. Böyle bir durumda bireyler kendilerini ahlaki yargılarıyla tutarlı davranmaya daha fazla mecbur hissedeceklerdir. Bu yaklaşım biçimine göre, eylemin motivasyonu ile ahlaki kavrayış arasında doğrusal bir bağlantı vardır; ahlaki motivasyon önemli oranda ahlaki kavrayıştan kaynaklanır. ${ }^{2}$ Kısacası, ahlaki motivasyon büyük ölçüde ahlaki yargı süreci ile açıklanabilir

Pekâlâ, bu kadar basit midir? Gerçek ahlaki bir ikilemle karşı karşıya kalan herkes, durumun bu kadar da basit olmadığını bilir. Çoğu insan kendisini ilkeli bulur ve çoğu zaman ilkeleriyle tutarlı davrandığına inanır. İlkelere sahip olmak soyut olarak takdire şayandır, ancak günlük yaşamın cazibeleri ve baskıları çoğu zaman çıkarları teşvik eder. İnsanlar, bazı eylemlerin doğru veya yanlış olduğuna ikna olsalar da belirli koşullara sahip belirli durumlarla karşılaştıklarında, izlenecek yol hakkında o kadar emin olamayabilirler. Başka bir deyişle, kritik süreçlerde bireylerin karşı karşıya kaldığı durumlar söz konusu olduğunda, bireylerin doğruya ilişkin bilgileri onlara tam anlamıyla rehberlik edemeyebilir. ${ }^{3}$ Açıkça görüldüğü üzere, insanların bilişsel düzeyde neyin doğru neyin yanlış olduğunu bilmeleri onların bu bildiklerini he zaman uygulayacakları anlamına gelmez. Ahlaki yargının ahlaki eylem üzerinde her zaman yeterince etkili olmaması 'ahlaki eylemi tam olarak motive eden şey nedir?' sorusunu tekrar gündeme getirmiştir. Bu da ahlaki yargı-eylem boşluğunu kapatmaya yardımcı olabilecek başka etkenlere yönelik bir arayışı hızlandırmıştır. $\mathrm{Bu}$ durum doğal olarak ahlaki akıl yürütmenin ötesine bakma konusunda daha fazla ilgiye neden olmuştur. Ahlaki kimliğin bu yargı-eylem boşluğunu gidermeye yardımcı olabileceği, ahlaki motivasyon ve bağlılığın daha iyi anlaşılmasını sağlayabileceği ve ahlaki gelişimin önemli bir bileşeni olabileceği düşüncesi bu yeni arayışlara temel olmaktadır. ${ }^{4}$ Muhakeme/yargı ve eyleme geçme arasında bir boşluk vardır; ahlaki kimlik çalışmaları ahlaki yargı ile ahlaki eylem arasındaki bu boşluğu doldurmayı hedeflemektedir. Dola-

1 David Carr, "Character Education as the Cultivation of Virtue", Handbook of Moral and Character Education, ed. Larry P. Nucci, Darcia Narvaez, (New York: Routledge, 2008), s. 101; Sam A. Hardy and Gustavo Carlo, "Moral Identity: What Is It, How Does It Develop, and Is It Linked to Moral Action?", Child Development Perspectives, Volume 5, Number 3, (2011), s. 212 .

2 Sam A. Hardy, Gustavo Carlo, "Identity as a Source of Moral Motivation", Human Development 48, (2005), s. 2; Hardy and Carlo, "Moral Identity: What Is It, How Does It Develop, and Is It Linked to Moral Action?", s. 212.

3 Ronald Duska and Mariellen Whelan, Moral Development: A Guide to Piaget and Kohlberg, ed. Ronald Duska and Mariellen Whelan, (New York, Paramus, Toronto: Paulist Press, 1975), s. 2.

4 Hardy and Carlo, "Moral Identity: What Is It, How Does It Develop, and Is It Linked to Moral Action?", s. 212. 
yısıyla ahlaki kimlik ve ahlaki eylem arasındaki ilişkinin doğasına yönelik bir çözümleme bu çalışmanın temelini oluşturmaktadır.

$\mathrm{Bu}$ yeni arayış biçimlerine bağlı olarak kişilik, benlik ve kimlik kavramlarının ahlaktan hareketle incelenmesi de yaygınlaşmıştır. Burada bilişsel yaklaşımların ahlaki alandaki değeri bütünüyle göz ardı edilmeden ahlaki benliğin ahlaki işleyişteki önemine vurgu yapılmaktadır. Kişi kavramının ahlaki kavramlardan bağımsız bir şekilde tanımlanamayacağı; benliğin veya kişiliğin ahlaki boyutlarının ihmal edilemeyeceği düşüncesi bu yeni yaklaşımlara temel olmaktadır. Nitekim ahlaki kavramlar, kişi olmanın ne anlama geldiğinin tam merkezinde bulunduğu için 'kişi olmak ne demektir?' gibi bir soru ancak ahlaki bir zeminden hareketle yanıtlanabilir. Ahlaki kavramlar, yaşanmaya değer olan bir hayatı 'iyi' yaşamanın neliğine dair düşünceye tesir etmektedir. Kişi olma ile ahlaki kavramlar arasındaki özsel bir ilişkinin varlığı dikkate alındığında çocukların ahlaki gelişimi, gelecek nesli eğitmekle görevli ebeveynlerin, okulların ve toplulukların temel ilgi alanıdır. Dolayısıyla çocukları belirli türden kişiler olarak yetiştirmenin kayda değer bir önemi vardır; ve böyle kişiler olmak herkes için önemli olmalıdır. ${ }^{5}$ Bu bakımdan, ahlaki alanı göz önünde bulundurmadan kişi olmanın tam olarak ne anlam ifade ettiğini ortaya koymak mümkün olmadığı gibi kişinin ne türden bir eğitimden geçmesi gerektiğini tam olarak ortaya koymak da mümkün değildir.

Ahlaki kimliğe ilişkin tartışmaların tarihsel süreç içinde bir karşılığ1 vardır. Ahlaki kişiliğin/benliğin son dönemlerde öne çıkması, onun ahlak teorisinde hiç bulunmadığı anlamına gelmemelidir. Sözgelimi Aristotelesçi etik gelenek, erdemlere vurgu yaparak benliğin ahlaki boyutuna dikkat çekmiştir. Benzer biçimde, Kant' $1 n$ ahlak teorisinde insan kavramının taşıdığı anlam ahlaki özne (moral agent) kavramından hareketle belirlenmiştir. Bu tanımlamaya göre ahlaki bir özne olmaksızın bir varlığın 'insan' olarak tanımlanmasından söz edilemez. Kant'a göre özerk bir özne olan ahlaki 'ben (self)' arzular ve tutkular gibi ampirik gerçekler tarafından belirlenmiş bir kişi değildir. Ahlaki benlik nedensel unsurlar tarafından sınırlanmayan ve rasyonel isteme (willing) yeteneğine sahip olan numenal bir öznedir. Bu nedenle, Kantçı düşünce açısından, kişi fenomenal karakterine ait olan her şeyden soyutlandıkça çeldirici tutkuların/ihtirasların etkisinden ve deneyimlerin determinizminden tamamen bağımsız olabilir. Nitekim fenomenal özne ampirik/deneysel nitelikler tarafından sınırlandığı halde numenal özne için böyle bir sınırlamadan söz edilemez. ${ }^{6}$

Görüldüğü üzere, ahlaki kişilik, benlik ve kimlik tartışmaları her zaman farklı teorik gelenekleri ve metodolojileri çağrıştıran farklı literatürlerde ve çalışma alanlarında bulunabilir. Burada herkes tarafından kabul edilen ortak bir yaklaşım olmasa da her bir yaklaşımın söz konusu tartışmaya katkıda bulunduğunu söylemek mümkündür. Elbette burada bütün kimlik ve benlik teorilerini tartışmak mümkün değildir ve böyle bir tartışma bu çalışmanın sınırlarını da aşan bir durumdur. O nedenle bu çalışma kimliğin ahlaki işleyişteki önemine; kimlik ve ahlak arasındaki bağlantının kavramsal boyutuna yönelik bir çerçeveyle sınırlandırılmıştır. Ahlaki kişilik/benlik çalışmaları doğal olarak ahlaki kimliğin doğasına yönelik bir çalışmayı zorunlu kılmaktadır. Kişiliğin ahlaki boyutlarının en iyi nasıl anlaşılabileceği ve neyi gerektirebileceği son derece önemlidir. Bu çalışma, 'Ahlaki kimlik nedir? Ahlaki kimlik nasıl gelişir? Ahlaki benliğin imkânı nedir? Ahlaki kimlik ahlaki eylemle bağlantılı mıdır?’ gibi sorulardan hareketle ahlaki kimlikle ilgili literatürün mevcut durumunu değerlendirmeyi ve aynı zamanda ahlaki motivasyonla bağlantısını irdelemeyi hedeflemektedir. Nitekim kimlik ve ahlak arasındaki bağlantıları anlamak için ahlaki işleyişte kimliğin rolünü keşfetmek son derece önemlidir.

\section{KIMLIK, BENLIK, AHLAKI KIMLIK}

Kendisiyle önemli oranda özdeşleştiğimiz ve hayatımızı ondan hareketle düzenlediğimiz kimliğimizi nasıl tanımladı̆̆ımız son derece önemlidir. Kimlik nedir? Ben kimim? Hiç kuşkusuz bu sorular, isim ve soyağacı verilerek yanıtlanacak sorular değildir. Kişi açısından neyin hayati bir değer taşıdığı ile bu sorulara

5 Darcia Narvaez and Daniel K. Lapsley, Personality, Identity, and Character, ed. Darcia Narvaez and Daniel K. Lapsley, (New York : Cambridge University Press, 2009), s. 1-3.

6 Daniel K. Lapsley, "Moral Self-Identity as the Aim of Education", Handbook of Moral and Character Education, ed. Larry P. Nucci, Darcia Narvaez, (New York: Routledge, 2008), s. 31-32. 
verilecek yanıt arasında doğrusal bir bağlantı vardır. Başka bir deyişle, kişi kendisi açısından temel olanı anlayarak bu sorulara ancak doğru bir yanıt verebilir. Kişinin kim olduğunu bilmesi aynı zamanda nerede durduğunu bilmesidir. Öyle ki, kişinin kimliği, her durumda neyin iyi, neyin değerli olduğunu belirlemeye çalışan çerçeveyi/yapıyı (veya bakış açısını) sağlayan bağlılıklar (commitments) tarafindan tanımlanır. Kişi bundan hareketle yapılması gereken şeyin ne olduğunu belirlediği gibi neyi desteklemesi ya da neye karş1 çıkması gerektiğini de belirler. Bu da kişinin kimliğinin belirli bir durum karşısında onun tavır alma biçiminin (anlayışının) başka bir ifadesidir. ${ }^{7}$

Burada kişinin kim olduğunu bilmesi; kendi kimliğinin bilincinde olması ahlaki alanla ilişkili olan bir durumdur. Sözgelimi, kişi açısından 'İyi nedir? Kötü nedir? Yaşanmaya değer olan şey nedir? Ne yapıl(ma) malıdır?' gibi sorular ahlaki alana ilişkin sorulardır. Burada kimlik ile yön belirleme arasında özsel bir bağlantı söz konusudur. Kişi hakkında konuşulurken doğal olarak ahlaki yönelim hakkında da konuşmak gerekmektedir. Kişinin eylemlerini yönlendiren temel ahlaki bir çerçeve söz konusudur. Nitekim, kimliğimiz, bizim için neyin önemli olup neyin olmadığını anlamamıza imkân tanıyan şeydir. ${ }^{8}$ Charles Taylor'a göre kimliğimiz, benlik algımız (sense of self) ve 'iyi'ye ilişkin tasavvurumuz arasında temel bir bağlantı vardır. Öyle ki 'ben kimim?’ sorusu ancak ahlaki bir çerçeveden hareketle anlaşılabilir ve cevaplanabilir. Kişinin kim olduğunu bilmesi, nerede durduğunu (durması gerektiğini) bilmesinin başka bir ifadesidir. Kişi, iyi ve değerli olanın ne olduğunu; onaylaması, yapılması gereken şeyleri veya neye karşı çıkması gerektiğini kendi kimliğinin içeriğinden hareketle belirler ve kimliği kişiye bu anlamda bir çerçeve sunar. ${ }^{9} \mathrm{O}$ nedenle, ahlaki benlik, ahlaki kimlik ve ahlaki kişilik gibi kavramlar bir kişinin benlik algısında ahlaki yapıların merkeziliğini belirtmek için kullanılan kavramlardır.

Ahlaki kimlik konusunda önemli bir düşünür olarak bilinen Augusto Blasi’ye göre 'kimlik' kişinin varl1ğının merkezidir; yani, kişinin temel benliğidir. Blasi’nin kimlik yapısına ilişkin fikirlerini ahlaki çerçeveyle birleştirmek, kimliğin ahlaki eylem için bir motivasyon kaynağı olarak nasıl hizmet edebileceğine dair bir örnek teşkil eder. Ahlakın nesnel önemini anlamanın yanı sıra, birçok insan için ahlaki kaygılar da kim olduklarına dair algıları açısından önemlidir. Bununla birlikte, ahlaki kimlik içeriğine (örneğin, ahlaki değerler ve hedefler) sahip bu bireyler arasında kimlik deneyiminde değişkenlik vardır. ${ }^{10}$ Elbette bir şahıs aynı anda birden fazla kimliğe sahip olabilir. Örneğin, bir kişi kendini ahlaki bir kişi (kişi kimliği), bir öğrenci (rol kimliği) ve bir topluluk üyesi (sosyal kimlik), bir siyasi parti üyesi (siyasi kimlik) olarak tanımlayabilir. Bütün bunlarla birlikte bireyler, kendileri için zorunlu olduğunu düşündükleri kişisel niteliklere göre farklılaşırlar. Bazıları temel nitelikleri olarak rekabet, nezaket veya samimiyet gibi nitelikleri temel alırlar. Her ne olursa olsun, bu kimlik onların hayatlarını düzenler, amaçlarını belirler ve yaşam boyu projelerini etkiler. ${ }^{11}$ Burada ası önemli olan kişinin hangi kimliğini bastırdığı ve hangisini öncelediğidir. Kişinin ahlaki bir kimliğe sahip olabilmesi veya ahlakın kişilerin kimliklerini inşa eden temel unsur olması için kişi ile ahlaki olgular arasında öncelikli bir bağın kurulması kaçınılmazdır.

Pekâlâ, kişinin bu kimlikleri onun ahlaki kimliğiyle nasıl iletişime geçmektedir? Buradaki bütün mesele bu kimliklerden hangisinin daha baskın olduğudur. Kişinin hangi kimliği onun diğer kimliklerine ilişkin eylemlerini yönlendirmektedir. Öyle ki bazı şahıslar açısından (onların) ahlakları kendi kimliklerin merkezinde bulunurken; diğerleri için ahlak kendi kimlikleri için çevresel (peripheral) bir statüye sahiptir. Hatta bazıları ahlakın, kişinin kendi kişisel hedeflerine ulaşmasını kısıtlayan ve hatta engelleyen, sosyal olarak kendisine dayatılan bir düzenleme sistemi olduğunu düşünebilir. ${ }^{12}$ Sözgelimi, bir futbol takımının üyesi olmak, kişinin çevresel kimliğinin bir parçası olarak bir anlam ifade edebilir; ancak öz-kimliğini bir

$7 \quad$ Charles Taylor, Sources of the Self: The Making of the Modern Identity, Harvard University Press, 1989), s. 27.

8 Taylor, Sources of the Self: The Making of the Modern Identity, s. 28-30.

9 Ben Spiecker and Jan Steutel, "Moral Identity and Education in a Multicultural Society", Studies in Philosophy and Education 15: 159-165, (1996), s. 163.

10 Hardy, Carlo, "Identity as a Source of Moral Motivation", s. 7.

11 Jan E. Stets and Michael J. Carter, “The Moral Self: Applying Identity Theory”, Social Psychology Quarterly, Vol. 74, No. 2, (2011), s. 194, 211.

12 Roger Bergman, "Why Be Moral? A Conceptual Model from Developmental Psychology", Human Development, (2002), s. 115 . 
spor takımı bağlamında sağlayan kişinin ahlaki açıdan yetersiz olduğunu söylemek mümkündür. ${ }^{13}$ Bu gibi durumlarda, ahlaki unsurlar kişinin kendi kimliğiyle bütünleşmediği için kişinin ahlaki inançlarına göre hareket etmekte başarısız olma olasılığı söz konusu olacaktır. Eğer bir birey özsel olarak kendisini ahlaki varlık olarak tanımlıyorsa, o zaman bu ahlaki kimlik 'gerçek ben', 'gerçek benlik' kabul edilir; ve bireyi yönlendiren en derin ilke olarak deneyimlenir. ${ }^{14}$

Çoğu insan kendisini ilkeli olarak düşünür ve çoğu zaman ilkeleriyle tutarlı davrandığına da inanır. Teorik anlamda ilkelere sahip olmak iyidir. Fakat çoğu zaman yaşamda karşılaşılan durumlar kişiyi ahlaki ilkelerinden vazgeçirebilir. Burada ahlaki inançlar ve eylem arasındaki ilişkinin gücünü belirleyen şey ahlaki ilkelere olan kişisel bağlılığın gücüdür. Kişisel bağlılık, öz-sistemi (veya benliği) ahlaki ilkelere bağlayarak, bu ilkelerle tutarlı bir şekilde davranma zorunluluğunu ve ilgili eyleme yönelik bir sorumluluk duygusunu üretir. Böylece kişi etik başarısızlıklara-ihlallere göz yummada isteksiz olduğu gibi bu etik başarısızlıkları-ihlalleri rasyonalize etme konusunda da isteksiz olur. İlkeli tutum, ahlaki ilkelerin var olduğu ve eyleme rehberlik etmesi gerektiği fikrini içerir. Öyle ki ilkelerin durum ötesi bir niteliği vardır. Kişisel sonuçlara veya kendi kendine hizmet eden rasyonelleştirmelere bakılmaksızın ilkeler takip edilmelidir. İlkelere sarsılmaz bağl1lık kişinin kimliğinin hayati/temel bir niteliğidir; üst düzeyde kişisel bağlılık ve ilkeli bir tutum, olayları yorumlamak ve eylemleri yönlendirmek için baskın bir şema haline gelmektedir. ${ }^{15}$

Görüldüğü üzere, ahlaki inançlar ve benlik ayrı ayrı sistemler değildir; her ikisi iç içe geçmişlerdir. Taylor'ın da ifade ettiği gibi, bir insan, bir kişi veya bir ben olmanın ne olduğuna yönelik bir analiz yapıldığında benlik ve ahlakın ayrılmaz bir şekilde iç içe geçmiş temalar olarak ortaya çıktığı görülmektedir. $\mathrm{O}$ halde kişi/ben olmak, ahlaki meseleler alanındaki varoluştan ayrılamaz. ${ }^{16} \mathrm{Bu}$ çerçeveden bakıldığında Blasi, benliği parçalayan (fragmentation) yaklaşımlara karşı direnmektedir; kişiliğin birleştirici bir merkezinin olduğunu savunmaktadır. Bu nedenle o, ahlaki kavramları güçlü bir iradeye veya sadece karakterin işlevlerine indirgeyen yaklaşım biçimlerine karşı çıkmaktadır. Blasi, ahlaki meseleleri bireyin kişisel yaşamından ayrılmış soyutlamalar olarak ele alan ve kişiliği temel almayan (depersonalization) çabalara da karşı çıkmaktadır. Blasi, özne olarak sorumlu olan ve ahlaki işleyişte iyi iradeyi önceleyen ahlaki benlikte 1srar etmektedir. ${ }^{17}$ O'nun için ahlaki yargı ile ahlaki eylem arasındaki kayıp/eksik halka ahlaki benliktir. Özellikle, ahlaki işleyişi anlamak için kişinin ahlaki kimliği son derece önemlidir. Öyle ki, ahlaki ilkelere bağl1lık yerine, ahlaki benliğe olan sadakat kişinin ahlaki olarak hareket etmesini sağlar. ${ }^{18}$ Buna göre, ahlaki benliğe olan bağlılık ile ahlaki eylemde bulunmak arasında doğrusal bir ilişki söz konusudur. Bu da benlik kavramının ahlaki bir ontolojiyi barındırdığını göstermektedir.

Ahlaki referanslardan hareketle inşa edilmiş benlik ahlaki kimliğin de merkezinde olmalıdır. Bu şekilde inşa edilmiş bir benliğin ahlaki kavrayış ile ahlaki eylem arasındaki uyumu sağlaması daha kolay olacaktır. Nitekim bir kişinin ahlaki yargı düzeyi, kişinin hayatındaki ahlakın yerine yönelik görüşlerini tam olarak belirlemeyebilir. Bir kişinin bu sorunu nasıl aştığını bilmek için, sadece kişinin ahlaki inançlarını değil, aynı zamanda bu ahlaki inançlarla ilgili olarak kişinin benlik anlayışını da bilmek gerekir. ${ }^{19} \mathrm{O}$ halde maksatlı bir özne olan benliğin ahlaki gerekçelere referansla oluşturulması son derece önemlidir. Benlik ahlaki taahhütler/bağlılıklar etrafında örgütlendiği ölçüde kişi ahlaki bir kimliğe sahip olur. Kişinin kendisini anlamasında/tanımlamasında ahlaki unsurların önemli ve zorunlu olmaları ile kişinin ahlaki bir kimliğe sahip olması arasında doğrusal bir bağ vardır. Buna göre, ancak ahlaki referansları temel alarak kendisini tanımlaması/anlaması kişiyi ahlaki bir kimliğe sahip kılacaktır. Ahlaka yönelik derin ve motivasyonel bir

13 Sean Riley, "Moral Identity and Moral Education: A Roycean Proposal for School Choice”, The Pluralist, Vol. 2, No. 2 (2007), s. 95.

14 Stets, Carter, "The Moral Self: Applying Identity Theory”, s. 194.

15 Barry R. Schlenker, Marisa L. Miller, Ryan M. Johnson, "Moral Identity, Integrity, and Personal Responsibility", Personality, Identity, and Character, ed. Darcia Narvaez and Daniel K. Lapsley, (New York : Cambridge University Press, 2009), s. 316.

16 Taylor, Sources of the Self: The Making of the Modern Identity, s. 2.

17 Daniel K. Lapsley and Darcia Narvaez, Moral Development, Self, and Identity, ed. Daniel K. Lapsley and Darcia Narvaez, ( London: Lawrence Erlbaum Associates, 2004), s.viii.

18 Stets, Carter, "The Moral Self: Applying Identity Theory”, s. 194.

19 Bergman, "Why Be Moral? A Conceptual Model from Developmental Psychology", s. 112. 
yönelim ile tanımlanan ahlaki benlik, böylece, 'iyi niyet' ile aşılanmış bir kişilik edinecektir. ${ }^{20}$ Benliğin ahlakla birleşiminin bir sonucu olarak da ahlaki kimlik ortaya çıkmaktadır. Buna göre, ahlaki kimlik gelişiminin amacı, benlik-ahlak bütünleşmesidir. Böylesi bir bütünleşmede kişisel kaygılar ile ahlaki kaygılar birleşmiştir. Ahlaki kişiliğe sahip bir birey, ahlaki kaygıları benlik kavramının merkezine yerleştirir ve ahlaki kaygılarıyla tutarlı bir şekilde yaşama zorunluluğunu hisseder. ${ }^{21}$

O halde ahlaki kimlik genel olarak, ahlaki bir kişi olmanın bireyin kimliği için önemli olma derecesini ifade eder. Eğer 'iyi', 'doğru', 'şefkatli', 'merhametli' veya 'adil' olmak gibi ahlaki kavramlar kişinin kendisini tanımlaması için temel olarak görülüyorsa, bu kişinin ahlaki bir kimliğinden söz edilebilir. Bu açıdan bakıldığında, kişinin ahlaki bir kimliğe sahip olması ile bu sıfatlara ne ölçüde karar/değer verdiği arasında doğrusal bir ilişki vardır. Bir kişi ahlaki sıfatlara sahip olduğu ölçüde ve yine kendisini bu tür sıfatlardan hareketle tanımladığı sürece o kişinin ahlaki bir kimliğe sahip olduğu söylenebilir. Dolayısıyla, kişinin (ahlaki sorumlulukları tanımlayan) bu kimliğe olan inancını sürdürmeye çalışması onun ahlaki bir kimliğe sahip olmasının temel koşuludur. Öyle ki bu kişi, ahlaki yükümlülükleri yaşamayı bir seçenek olarak hissetmez, bir zorunluluk olarak hisseder. ${ }^{22} \mathrm{Bu}$ da kişilik bağlamında ahlakın incelenmesi gibi bir tutumun ortaya çıkmasına neden olmaktadır. Burada ahlaki kimlik ahlakın ve benliğin birliği olarak kabul edilmektedir. Öyle ki son derece ahlaklı olan insanları diğerlerinden ayıran şey, onların ahlak anlayışları ile kişisel hedefleri arasındaki birliği deneyimleme derecesidir. Diğer bir deyişle, ahlaklı insanların ahlaki olarak doğru gördükleri ne ise en çok istedikleri şey de odur. Kişisel ve ahlaki hedeflerin bu tür bir entegrasyonu/birleşimi, güçlü bir ahlaki motivasyon ve bağl1lık kaynağı olarak hizmet edebilir. ${ }^{23}$

Ahlaki kimlik erdemlerden hareketle inşa edilir ve bütün erdemler ahlaki açıdan aynı düzeyde olmayabilir. Kişinin kimliği ne kadar yüksek erdemlerden oluşursa kişinin ahlaki hedeflerini gerçekleştirmesi o düzeyde kolay olacaktır. Elbette daha yüksek dereceli erdemlerin var edilmesi çok kolay değildir ve bu erdemler önemli oranda 'irade gücü (öz denetim)' ve ‘öz-tutarlılık (self-consistency)' gibi nitelikleri gerektirmektedir. İrade gücü veya öz-tutarlı1ık olmaksızın sözgelimi, sözünün insanı olma, kendine karşı şeffaf olma, sorumluluk sahibi olma, hesap verebilir olma, kendini kandırmaya karşı dirençli olma gibi erdemlere sahip olmak zorlaşacaktır. Kişi, ahlaki olan hedeflerini gerçekleştirmeye çalışıp kendini kasıtlı olarak kontrol etme eylemleriyle sınırlandırdığında bu tür erdemler aynı zamanda kişi tarafindan sorumluluk olarak hissedilir/anlaşılır. ${ }^{24}$ Kişinin kimliği ne kadar üst düzey erdemlerden oluşursa kişinin ahlaki hedeflerinin gerçekleşmesi de o düzeyde kolay olacaktır. Hiç kuşkusuz, bireyin ahlaki hedeflerini gerçekleştirmeye olan bağlılı̆̆ı, eylemde sadakati ve kendisiyle tutarlı olma kaygısı benlik algısının en önemli bileşenleridir. Öyleyse içten bir bağlılık, sadakat ve tutarlılık gibi nitelikler ahlaki kimliğe kavramsal bir içerik kazandırmaktadır. Bu kavramlardan yoksun bir ahlaki kimlik tanımlanması eksik veya sorunlu bir tanımlama olacaktır. ${ }^{25}$ $\mathrm{O}$ halde bir birey kendi kişisel kimliğini tanımlamada temel değerlerin merkezi bir statüye sahip olduğunu düşünüyorsa, ancak o zaman onun güçlü bir ahlaki kimliğe sahip olduğunu söylemek mümkündür.

Görüldüğü üzere ahlaki kimlik, bu makalede bir dizi ahlaki özellik etrafında düzenlenen bir benlik kavramı olarak tanımlanmaktadır. Ahlaki yargı ve eylem arasında bir tutarlılığın sağlanmasında kişinin sahip olduğu ahlaki kimlik temel bir değer taşımaktadır. Kişinin karşılaşacağı ahlak-dışı durumlarla başa çıkabilmesi için onun ahlaki kimliğinin sıkı bir şekilde inşa edilmesi gerekmektedir. Yargı eylem bütünlügü ahlaki kimliğin sağlam olmasıyla orantılıdır. Her şey 'kişi'nin kendisini ve sorumluluklarını nasıl anladığına bağlıdır. Kişinin kendisini tanımlama biçimi veya kendisini hangi kavramlardan/referanslardan hareketle tanımladığı ile o kişinin eylemlerinin biçimi arasında sıkı bir ilişki vardır. Blasi’nin iddia ettiği gibi 'ahlaki muhakeme', ahlaki eylemi etkileyen bir motivasyon gücüne sahiptir. Ahlaki bilgi, benlikle bütünleşip kişi-

20 Lapsley, Narvaez, Moral Development, Self, and Identity, s. Vii.

21 Darcia Narvaez, "Neurobiology and Moral Mindset", Handbook of Moral Motivation, (ed), Karin Heinrichs, Fritz

Oser and Terence Lovat, (Rotterdam: Sense Publishers, 2013), s. 323.

22 Lapsley, "Moral Self-Identity as the Aim of Education", s.35-37.

23 Hardy and Carlo, "Moral Identity: What Is It, How Does It Develop, and Is It Linked to Moral Action?", s. 213.

24 Lapsley, "Moral Self-Identity as the Aim of Education", s. 36.

25 Tobias Krettenauer and Steven Hertz, "What Develops in Moral Identities? A Critical Review", Human Development, Vol. 58, No. 3 (2015), s. 140. 
nin neliğini belirlemede (ahlaki bir kimlik olarak) zorunlu hale geldiği zaman, onun ahlaki eylemi etkilemede temel bir faktör olacaktır. ${ }^{26}$ Özetle, ahlaki muhakeme ve bilişsel ahlaki gelişim ahlaki işleyişte gerekli olmakla birlikte ahlaki eylem için yeterli değildir. Ahlaki eylemi açıklamada önemli değişkenler olmalarına rağmen, bunlar hikâyenin sadece bir parçasıdır. Bir dizi ahlaki idealin önemli bir parçası olduğuna gerçekten inanan bir kişi, ideal benliğini ve dolayısıyla kim olduğunu tanımlar. ${ }^{27}$ Böylece ahlakın bilişsel temeli korunarak ahlaki işleyişi daha uygun bir şekilde açıklamak için benliğe dahil edilmiştir.

\section{AHLAKI KIMLIK-AHLAKI EYLEM}

Ahlaki eylemi motive eden veya gerçekleşmesini sağlayan şeyin ne olduğuna ilişkin farklı görüşler vardır. Sözgelimi, Kohlberg'in bilişsel gelişim teorisi, büyük ölçüde ahlaki muhakemenin rolüne odaklanarak son derece etkili olan bilişsel-gelişimsel ahlak teorisini inşa etti. Kohlberg, ahlaki ilkelerin anlaşılması durumunda ahlaki eylemleri motive edeceğini varsaymaktadır. Ahlaki muhakeme geliştikçe, ahlaki durumlarda hüküm vermesi gereken bireyler ahlaki ilkeleri kullanmaya daha yatkın hale gelecektir. Ahlaki muhakemenin daha yüksek aşamalarında, ahlaki ilkeler ve bunların evrensel ve kuralcı doğası daha belirgin olacaktır. Böyle bir durumda bireyler kendilerini ahlaki yargılarıyla tutarlı davranmaya daha fazla mecbur hissederler. O halde ahlaki eylemin motivasyonu ile ahlaki kavrayış arasında doğrusal bir bağlantı vardır ve ahlaki motivasyon önemli oranda ahlaki kavrayıştan kaynaklanır. ${ }^{28}$

Son dönemlerde ise ahlaki motivasyon için ahlaki kimliğin (ahlaki benliğin) önemine vurgu yapan yaklaşımlar ön plana çıkmaktadır. Örneğin Blasi, ahlaki kimlikte ahlaki ilkeler, hedefler ve taahhütler gibi ahlaki kaygıların kişinin motivasyonel ve duygusal sistemleriyle bütünleştiğini öne sürmektedir. ${ }^{29}$ Burada ahlaki kimlik ahlaki eylemi belirlemede son derece önemli bir motivasyon kaynağı olarak kabul edilmektedir. O nedenle ahlaki kimliğin ahlaki eylem üzerindeki etkisinin ne olduğu veya ne olabileceği birçok araştırmaya konu olmuştur. Ahlaki kimliğin ahlaki yargıyı nasıl etkilediği; ahlaki kimliğin ve ahlaki yargının ahlaki eylemi şekillendirmek için nasıl birlikte etkileşime geçtikleri son derece önemlidir. Pekâlâ, ahlaki kimlik ile ahlaki eylem arasında ne tür bir ilişki vardır? Bireylerin ahlaki kimlikleri eylemelrini yönlendirmekte midir? Ahlaki kimlik ile ahlaki eylem arasındaki ilişkilerin nedensel doğası nedir? Ahlaki kimliği ahlaki eyleme bağlayan mekanizmalar nelerdir? Ahlaki kimlik ile ahlaki eylem arasındaki bağlantılara hangi faktörler aracılık edebilir veya bunları azaltabilir?

Ahlaki alan bireyin önemli oranda yaşam alanıyla ilgilidir. Burada kişinin sadece bilgiye sahip olması değil; aynı zamanda bunu uygulaması dikkate alınır. Bireylerin ahlaki bilgileri doğrultusunda hareket etmeye karar vermeleri son derece önemlidir. Örneğin, bir adam belirli bir durumda başkasına yardım etmenin en ahlaki şey olduğuna ve bu durumda yardım etmekten sorumlu olduğuna karar vermiş olsa bile, yine de yardım etmeyi seçmesi gerekecektir. Bu nedenle, ahlaki yargı eylemi etkileyen bir tutum olarak görülse de nihayetinde bir davranışsal niyet kararı verilmelidir. ${ }^{30}$ Öyle ki doğru ahlaki tutumlara sahip olan ve bu tutumlarına uygun hareket eden kişilerin ahlaki açıdan olgun bireyler oldukları düşünülür. Bireyin teorik düzlemdeki tutumu ile pratik düzlemdeki tutumu arasında bir uyuşma olmalıdır. O nedenle 'iyi' hakkında konuşmaktan veya 'iyi olanı' bilmekten ziyade 'iyi olmak' daha temeldir. İnsanların tüm bilgisi ve gelişmişliğine rağmen insan kaynaklı hava kirliliği, insan hakları ihlali, iklim değişikliği, ekonomik adaletsizlik gibi pek çok sorun bulunmaktadır. Pekâlâ, insanlar böylesine büyük bir bilgiye, bu kadar çok kavrayışa rağmen neden ahlaki davranmıyorlar? Onların ahlak-dışı eylemelerinin sebebi ne olabilir? Ahlaki yargılarına göre, yapılması gerekene ilişkin tutarlı davranmalarını engelleyen nedir?

Hiç kuşkusuz kişinin ahlaki yargı düzeyi ile ahlakın söz konusu kişinin yaşamındaki yeri arasında her zaman doğrusal bir ilişki bulunmamaktadır. Yeterli düzeyde bir epistemeye sahip olduğu halde bunu ahlaki

26 Stets, Carter, “The Moral Self: Applying Identity Theory”, s.194.

27 Karl Aquino, “ The Self-Importance of Moral Identity”, Journal of Personality and Social Psychology, Vol. 83, No. 6, (2002), s.1425.

28 Hardy, Carlo, "Identity as a Source of Moral Motivation", s. 2.

29 Hardy, Carlo, "Identity as a Source of Moral Motivation", s. 1.

30 Hardy, Carlo, "Identity as a Source of Moral Motivation", s. 20. 
eyleme dönüştür(e)meyen bir çok örnek söz konusudur. O nedenle birçok araştırmacı, bilişsel gelişim teorisinin belli birtakım sınırlılıklar içerdiğini söylemekte ve kimlik teorisinin daha iyi bir açıklama olabileceğini iddia etmektedir. Daha önce de belirtildiği üzere, ahlaki kimlik konusunda önemli bir düşünür olarak bilinen Blasi, kimliği kişinin varlığının merkezi olarak tanımlamakta; ahlaki yargı ve eylem arasındaki bağlantıyı ele alan benlik modelini ortaya koymaktadır. Ahlaki bir yargı ahlaki eylemi doğurmadan önce bir sorumluluk yargısından geçebilir. Bir eylem sadece ahlaki değil, aynı zamanda kişinin yapmaktan sorumlu olduğu bir şey olarak görülebilir. Bir kişinin kimliği ahlak merkezli olursa o zaman, kişinin kendi benlik algısıyla tutarlı bir şekilde yaşama isteği, temel bir ahlaki motivasyon görevi görebilir. Kısaca, diyor Blasi, eğer ahlaki yargılar kişinin kimliğine dayanan sorumluluk düşüncesi tarafından süzülürse bunların ahlaki eylemi öngörmesi daha olası olacaktır. ${ }^{31}$

Buradaki temel iddia ahlaki eylemlerin hem ahlaki yargının hem de ahlaki kimliğin sonucu olduğudur ve ahlaki kimliğin ahlaki yargi ile ahlaki eylem arasındaki boşluğu doldurduğudur. Ahlaki kimlik, kişinin kimliğindeki ahlaki değerlerin önemini ifade eder. Bazı bireyler için, ahlaki düşünceler günlük yaşamda bol miktarda bulunur çünkü ahlak, bu bireylerin varlıklarının merkezine yerleşmiştir. Oysa diğer bireyler için ahlaki standartlar ve değerler, onların günlük faaliyetlerinde ve benlik algılarında o kadar belirgin değildir. Güçlü ahlaki kimliğe sahip bireylerin sahip oldukları ahlaki şemalardan dolayı belirli bir durumun ahlaki boyutlarını göz önünde bulundurmaları ve ahlaki kaygılarını diğer kaygılardan öncelemeleri daha olasıdır. Maliyet-fayda analizini yapmak ve sonuca dayalı bir yaklaşım benimsemek yerine, güçlü ahlaki kimliğe sahip bireylerin ilkelere başvurmaları ve ahlaki kararlarla karşılaştıklarında ilke temelli bir yaklaşım benimsemeleri muhtemeldir. ${ }^{32}$ Kendilerini ahlaki kimlikleriyle tanımlayan bireylerin çevrelerindeki ahlaki sorunları belirleme, en makul eylemleri belirlemeyle uğraşma, harekete geçme yükümlülüğü hissetme ve makul çözümler geliştirme olasılıkları daha yüksek olmalıdır. ${ }^{33}$

Kimlik teorisinde de bireyler kendi kimliklerinin anlamlarını temel alarak eylemde bulunurlar. Bireylerin söz konusu eylemlerinin anlamları ile kimliklerinin anlamları arasında bir tutarlılık olmalıdır. Başka bir deyişle, kişilerin eylemelri kendi kimliklerinin anlamlarından hareketle gerçekleşir. Tutarsızlık olumsuz duygular ürettiği için bireyler kendi kimliklerinin anlamlarıyla çelişecek şekilde hareket edebilirler. ${ }^{34}$ Nitekim, düşünce ve eylem arasındaki tutarsızlık rasyonalitenin temel ilkelerinin ihlali anlamına gelmektedir. Kişinin ahlaki koduna ilişkin bir tutarsızlık aynı zamanda bir mantıksızlığa tekabül ettiği için, kişinin mevcut ahlaki kodunu değiştirmesi kaçınılamazdır. Kaldı ki düşünce ve eylem arasında tutarlılık üretmeyen bir kodun zaten şimdiye kadar mantıksız olduğu açıktır. Mevcut ahlaki koddan veya ahlaki akıl yürütmeden kurtulmadan tutarlı bir davranış biçimi ortaya çıkarmak mümkün olmayacaktır. Örneğin, kişi teorik anlamda adaletli olmayı savunup pratikte bunu gerçekleştiremiyorsa bu bir tutarsızlıktır ve kişinin ahlaki akıl yürütmesi veya ahlaki kodu problemlidir. Kişi adalet adına eylemde bulunuyorsa bu kişi de (rasyonel bir özne olarak) benzer durumdaki bütün rasyonel öznelerin bağlı bulundukları ilkelere bağlı olmalıdır; o ilkelere göre eylemde bulunmalıdır. ${ }^{35}$ Bireyin sahip olduğu ahlaki kimliklerinin pratik sonuçları olmalıdır; ahlaki inanç ile ahlaki yargı arasındaki bu doğrusal bağ aynı zamanda tutarlılığın zorunlu kıldığı bir şeydir. Kaldı ki ahlaki yargı ile ahlaki eylem arasında bir uyuşma olmaması durumunda ahlaki olaylara olan ilginin azalması veya yıpranması da söz konusu olabilir. O halde ahlaki inancın eylemle olan uygunluğu, eylem ile ahlaki inancın kavramsal bağı, son derece önemlidir. Bireyler ancak ahlaki kimliklerinin anlamlarıyla uyumlu eylemeler ortaya koyduklarında söz konusu tutarsızlıktan uzaklaşacaklardır.

Kişinin ahlaki ideallerine veya ilkelerine uygun hareket etmesi, aynı zamanda kişinin eylemleri ve düşünceleri arasında bir tutarlılığın varlığına işaret eder. Bu durum çoğu zaman ahlaki değerler uğruna kişinin kendi çıkarını riske atmasına da bağlıdır. Bu tür bir ahlaki kimliğe sahip olan kişi başkalarını da ahlaki ey-

31 Hardy, Carlo, "Moral Identity: What Is It, How Does It Develop, and Is It Linked to Moral Action?”, s. 212.

32 Zhi Xing Xu, Hing Keung Ma, "How Can a Deontological Decision Lead to Moral Behavior? The Moderating Role of Moral Identity", Journal of Business Ethics , September 2016, Vol. 137, No. 3 (2016), s. 538-539.

33 Stephen J. Thoma, Muriel J. Bebeau "Moral Motivation and the Four Component Model", Handbook of Moral Motivation, (Rotterdam: Sense Publishers, 2013), s. 52.

34 Stets, Carter, "The Moral Self: Applying Identity Theory”, s.192.

35 Henry David Aiken, "Moral Reasoning", Ethics, Vol. 64, No. 1 (1953), s. 32. 
leme geçirme konusunda son derece isteklidir. ${ }^{36}$ Kişinin 'kişisel-çıkar kimliğì' ile ahlaki kimliği arasında bir çatışma olduğunda ve kişi kişisel-çıkar kimliğini öncelediğinde onun benliğinin olumsuz etkilenmesi kaçınılmaz olacaktır. Bireylerin birden fazla kimliği vardır, ancak bu kimliklerden bazıları kişinin kendi benlik algısıyla (self-concept) uyumlu çalışabilir. Fakat bu kimlikler ile kişinin benlik algısı arasında bir çatışma söz konusu olduğunda burada psikolojik bir gerilim ortaya çıkar ve bu gerilim de olumsuz duygulara neden olur. ${ }^{37}$ Sözgelimi Sokrates'e göre, toplumdaki adalet nasıl sınıflar arasındaki uyumlu/düzenli bir ilişki ise, bireydeki adalet de kişiliğin farklı yönleri arasındaki uyumlu bir ilişkiden oluşmaktadır. Nasıl ki kalp, akciğerler, duyu organları gibi kişinin farklı fiziksel organlarının tümü düzgün bir şekilde çalıştıklarında vücut sağlı̆̆ var oluyorsa, benliğin farklı boyutları uygun/gerekli olan işlevlerini yerine getirdiklerinde kişinin zihinsel sağlığ var olacaktır. ${ }^{38} \mathrm{O}$ halde kişiliğin farklı boyutları arasındaki uyum ile kişinin sağlığ bir ilişki vardır.

Bir kişinin ahlaki kimlik tutarsızlığı ne kadar yüksek olursa, o kişinin olumsuz duygular yaşama olasıl1ğ1 o kadar yüksektir. Ahlaki eylemde, suçluluk ‘kişiye acı veren bir saygısızlık hissi' olarak anlaşıldığında ahlaki gelişim için motivasyonel bir rol üstlenmektedir. Ahlaki kimliğin kendilerinden hareketle tanımlandığ 1 sıfatlara sahip birinin bu sıfatlara sahip olmasından dolayı kendisini 'iyi' hissetmesi ve bu sifatları kim olduğunun önemli birer parçası olarak görmesi anlaşılır bir durumdur. Kaldı ki kişinin kendini huzurlu hissetmesi veya duygusal sağlığı ile bu özelliklere sahip olması arasında da önemli bir bağlantı olabilir. ${ }^{39}$ Kişi ahlaki davranmaya devam eder çünkü ahlaki normlar ve idealler iyi ve arzu edilirdir. Ayrıca, kişinin temel taahhütlerine aykırı hareket etmesi aynı zamanda onun kendisine ihanet etmesi olacaktır ve bu da kişinin benlik duygusuna zarar verecektir. ${ }^{40} \mathrm{O}$ halde kişinin kendi kimliğine uygun eylemelerde bulunması aynı zamanda onu mutlu edebilecek bir durum olarak düşünülebilir.

Güçlü ahlaki kimliğe sahip bireyler, ahlaki kararlar verirken ahlaki ilkelerden hareket ederler. Bu bireyler ahlaki bir hüküm verirken önemli oranda ahlaki çerçeveye bağlı kalırlar. Zayıf ahlaki kimliğe sahip bireyler ise belirli bir durumun ahlaki bileşenlerini tanımada başarısız olabilirler. Bu kimseler ahlaki bir karar verirken faydacı idealleri tercih edebilirler. Bu durum, insanların çoklu ve hatta çelişkili bakış açılarından hareketle karar vermelerinin gerektiği durumlarda daha sık görülür. O halde, yaşamlarında ahlaki şemaları öne çıkan bireylerin ilke temelli bir zeminden hareketle eylemde bulunma olasılıkları daha yüksek olacaktır. ${ }^{41}$ Kaldı ki, ahlaki standartları ve ilkeleri başarıyla içselleştirmiş bireylerin yaşam deneyimlerinde ahlaki şemaların daha baskın olması son derece olasıdır. Böyle bir durumda onların ahlaki endişeleri diğer endişelerin önüne yerleştirdiklerini ve ahlaki davranma konusunda daha fazla motivasyona sahip olduklarını söylemek mümkündür. Ahlaki normları kendi iyiliği-çıkarı için kabul eden bir kişi ahlakı gerçekten anlamamış demektir. Ahlaki istemeleri kendi iyiliği için isteyenler ile sırf ahlak için isteyenler arasında bir ayrım yapmak; ahlaki yargılara içsel olarak bağlı olanları takdir ederek onlara saygı göstermek ahlaki eyleme yönelik iyi bir güdüleyici unsur olacaktır.

Pekâlâ, kişi bildikleriyle tutarlı bir şekilde eylemde bulunma motivasyonunu tam olarak nerden almaktadır? Blasi'ye göre ahlaki kavrayışın (understanding) benliğin veya kimliğin yapılarıyla bütünleşmesiyle motivasyon gücünün varlığı arasında doğrusal bir ilişki vardır. Bu teoriye göre, ahlaki kavrayış kişisel kimliğe şekil verirken, ahlakla özdeşleşme kişinin kişisel sorumluluk duygusunu şekillendirir ve ahlaki kavrayışın kişinin bildiğiyle/inandığıyla tutarlı bir şekilde hareket etme motivasyonunu ortaya çıkarır. Ancak bu türden bir bütünleşme veya bütünlük ahlaki açıdan olgun bireyin işareti olabilir. Kavrayış ve kimlik karşılıklı birbirini etkilemektedir. Kimlik ise sorumluluk düşüncesi ile motivasyonu etkilemekte ve bunlar da eylemi ortaya çıkarmaktadır. ${ }^{42}$ Bu çerçeveden bakıldığında denilebilir ki, ahlaki yargı ve ahlaki kimlik arasındaki etki ahlaki eylemin karmaşıklığını sınırlar. Ahlaki bir ikilem içinde bir ahlaki özneyi araba kul-

36 Bkz. Bergman, "Why Be Moral? A Conceptual Model from Developmental Psychology”, s. 115-116.

37 Stets, Carter, “The Moral Self: Applying Identity Theory”, s. 195.

38 Richard Norman, The Moral Philosophers, (Oxford: Oxford University Press, 1998), s.15.

39 Aquino, "The Self-Importance of Moral Identity", 1428.

40 Hardy, Carlo, "Identity as a Source of Moral Motivation", s. 8-9.

$41 \mathrm{Xu}, \mathrm{Ma}$, "How Can a Deontological Decision Lead to Moral Behavior? The Moderating Role of Moral Identity", s. 539.

42 Bergman, "Why Be Moral? A Conceptual Model from Developmental Psychology", s. 121-122. 
lanan bir adam gibi düşünelim. Ahlaki kimlik, gücü harekete geçiren gaz pedalı gibiyken ahlaki yargı da yönü kontrol eden direksiyon simidi gibidir. Kişinin ahlaki ikilemden başarıyla geçip ahlaki olarak doğru yere ulaşabilmesi için hem güce hem de yönlendirmeye ihtiyacı vardır. ${ }^{43}$ Kısacası ahlaki kavrayış veya ahlaki muhakeme ahlaki kimliğin motive edici gücü ile birleştiğinde, ahlaki eylem en yüksek seviyeye çıkar.

O halde ahlaki kimliği ahlaki eylemi motive eden bir tür özdenetim mekanizması olarak tanımlamak anlaşılır bir durumdur. Ahlaki kimlik, benimsenen diğer sosyal kimlikler gibi, insanların kendi kendilerini tanımlamak (öz-tanımlama) için kullandıkları kimliklerine bir temel olabilir. Diğger kimlikler gibi, bir kişinin ahlaki kimliği de belirli inançlar, tutumlar ve davranışlarla ilişkilendirilebilir. Güçlü bir ahlaki kimliğin yokluğunda, karmaşık ahlaki yargıları yerine getirme ve ahlaki argümanlar sunma yeteneği önemli oranda zayıflamış olacaktır. Nitekim ahlakın benlik üzerindeki merkeziyetinin ahlaki yargı ve eylem arasındaki uyumun en güçlü belirleyicisi olabileceğini söylemenin haklı nedenleri vardır. Benlik kavramlarını ahlaki inançları etrafında örgütleyen insanların, bu inançlarını yaşamları boyunca tutarlı bir şekilde eyleme dönüştürme olasılıkları daha yüksektir. Güçlü bir ahlaki kimliğe sahip insanların ahlaki benlik kavramları ile eylemleri arasındaki tutarlılığı sürdürmek için daha fazla çabaladıklarını söylemek mümkündür. Kişinin ahlaki kimliği onun benlik kavramıyla ne kadar bağlantılıysa o kişinin zaman içinde istikrarlı olma olasılığı daha yüksek olacaktır. ${ }^{44}$ İstikrarlı bir tutum sergilemek için kişinin ahlaki kimliği ile benlik tasavvuru arasında derin bir bağın olması gereklidir. Çünkü burada ahlak ve kimlik aynı gelişimsel sistemin iki yüzü olarak görülmektedir. Her birinin gelişimsel yolları o kadar uyumludur ki, bazıları ahlaki kimliği hem ahlaki hem de kimlik gelişiminin hedefi olarak görür. Ahlaki muhakemenin olgunluğu kendi başına önemli olsa da kimlikle bütünleşme daha fazla motivasyon ve bağlılık sağlar. Dahası, kimlik çeşitli şeylere dayandırılabilirken, ahlaka dayalı olması en ideal olanıdır. ${ }^{45}$

Sonuç olarak denilebilir ki ahlaki muhakeme ile ahlaki eylem arasındaki boşluğu doldurma girişiminde 'ahlak-benlik' birleşimi' önemli bir çözüm önerisi olarak ortaya çıkmaktadır. Ahlak ve kimlik ilişkisine yönelik düşünceleri açısından bu yaklaşım biçiminin en önemli savunucusu olan Blasi üç temel bileşene vurgu yapmaktadır: (i) Ahlaki bir yargı ahlaki eyleme dönüşmeden önce 'ahlaki olarak değerlendirilen bir eylem aynı zamanda birey için kesinlikle gereklidir’ gibi bir sorumluluk yargısından da geçebilir. Dolayısıyla, bir kişi belirli bir durumda ilerlemek için yalnızca 'doğru' veya 'ahlaki' yola karar vermekle kalmayabilir, aynı zamanda bu yargıya göre hareket etmekten kendisini sorumlu hissedip hissetmediğini de değerlendirebilir. (ii) Sorumluluk yargıları için kriterler genellikle bir bireyin benliğinin yapısından kaynaklanır. Ahlaki olmak, benlik duygusunun merkezi veya temel bir özelliği olduğu ölçüde kişi güçlü bir ahlaki kimliğe sahip olur. (iii) Bu yaklaşım biçiminin üçüncü bileşeni, öz-tutarlılıktır. Kişinin benlik duygusuyla tutarlı yaşamayı isteme yönünde doğal bir eğilimi vardır. Kişinin benliği ahlaki kaygılara odaklandığında, bu eğilim ahlaki eylem için kilit bir motive edici güç olarak hizmet eder. Özetle, diyor Blasi, ahlaki yargılar, ahlaki kimliğe dayalı sorumluluk yargılarıyla süzülür ve öz-tutarlılık eğilimi yoluyla eyleme itilirse, ahlaki davranışı daha güvenilir bir şekilde tahmin edebilir. Bu da öz-tutarlılık olarak ifade edilebilir. ${ }^{46}$

Ahlak, kişinin benlik ve kimlik duygusu için önemli ve merkezi olduğu zaman, kişinin ahlaki kayg1larıyla tutarlı olarak yaşama mecburiyeti ve sorumluluğu artmaktadır. Kişi aktif olarak ahlaki kaygılara odaklanan bir kimlik inşa ettiği ölçüde ahlaki bir kimliğe sahip olur ve bu kimlik, endişelerle tutarlı bir şekilde yaşaması için kişiye güçlü bir yükümlülük duygusu ve bağl1lık sağlar. ${ }^{47} \mathrm{O}$ halde ahlaki ilkelerin içselleştirilmesi son derece önemlidir. İçselleştirme, ahlaki niteliklerin benlik kavramının merkezinde yer edinmesidir. İçselleştirilmiş bir ahlaki ilkenin ahlaki yargı ve ahlaki eylemle kurmuş olduğu bağ son derece güçlü bir bağdır. Aksine, ahlaki kimliğin içselleştirilmiş boyutu belirgin değilse, ahlaki yargı anında ahlaki şemalara ve davranış kurallarına erişilemez. Böyle bir durumda bireye faydacı ideallerin, kişisel çıkarların hakim olması ve davranışın sonucunun ilkeleri öncelemesi kaçınılmaz olacaktır. ${ }^{48}$

$43 \mathrm{Xu}, \mathrm{Ma}$, "How Can a Deontological Decision Lead to Moral Behavior? The Moderating Role of Moral Identity", s. 547.

44 Aquino, "The Self-Importance of Moral Identity", s. 1423-1425.

45 Hardy, Carlo, "Moral Identity: What Is It, How Does It Develop, and Is It Linked to Moral Action?”, s. 213.

46 Hardy, Carlo, "Identity as a Source of Moral Motivation", s. 5-6.

47 Hardy, Carlo, "Identity as a Source of Moral Motivation”, s. 18.

$48 \mathrm{Xu}, \mathrm{Ma}$, "How Can a Deontological Decision Lead to Moral Behavior? The Moderating Role of Moral Identity", s. 546. 
Ahlak-benlik birliğini sağlayan bireyler için, ahlakla ilgili şemalar yaşam deneyimlerinde belirgindir. Bu tür bireylerin sonuca dayalı eylemden ziyade ilke temelli eyleme daha duyarlı olduklarını söylemek mümkündür. O halde ahlaki kimlik bireyi konuşmaktan daha çok ahlaki eylemde bulunmaya sevk eder. Nitekim düşük düzeydeki ahlaki kimlik sahibi bireylerin yanlış yapma olasılığını artırabilir. Buna karşın, ahlaki kimliği baskın oldukça bireyin etik-dışı eylemlerde bulunma olasılığı daha düşük olacaktır. Ahlaki kimlik ahlaki eyleme neden olur; başka bir deyişle ahlaki eylem kişinin ahlaki kimliği tarafından yönlendirilir.

\section{EĞiTIM VE AHLAKI KIMLIK}

Ahlaki referanslardan hareketle inşa edilmiş bir benlik ahlaki kimliğin de merkezinde olmalıdır. Benliğin ahlaki olmayan idealler üzerinden inşa edilmesi ahlaki kimlik açısından son derece sorunlu olacaktır. O nedenle ahlaki kimliğin merkezinde bulunan benliğin nasıl ve ne tür referanslardan hareketle inşa edildiği son derece önemlidir. Pekâlâ, insana varoluşsal bir değer katan ahlaki kimlik nasıl inşa edilecektir? Ahlaki kimliği veya ahlaki olgunlaşmayı mümkün kılan şeyler nelerdir? Ahlaki kimlik kişinin tek başına edindiği bir şey midir? Eğitim ve ahlaki kimlik gelişimi arasında ne tür bir ilişki vardır? 'İnsan olma' kimliğini belirleyen unsurlar dikkate alınmadan insanı eğitmek mümkün müdür?

Elbette ahlaki kimlik veya ahlaki olgunlaşmanın tek bir nedene indirgenerek açıklanması mümkün değildir. Fakat ahlaki kimlik tarafından şekillenen bir yaşam sürdürmeyi öğrenme ile bu kimliği besleyen bir topluluğa girme arasında sıkı bir ilişki vardır. Ahlaki kimliğe kavramsal bir içerik kazandıran erdemlerin öğrenilmesi için girdiği okul topluluğunun ahlaki bir topluluk olması önemlidir. Bu çerçeveden bakıldığında okulların da ahlaki topluluklar olmalarına ihtiyaç vardır. Eğitim, kişiye ahlaki bir kimlik kazandıracak ve aynı zamanda ahlaki bir dilin konuşulmasını kolaylaştıracak şekilde planlanmalıdır. Oysa, bazılarına göre, okullar eğitim kurumlarıdır; okulların etik idealleri beslemeyi temel amaç edinmeleri onların bilişsel sorumluluğunu ortadan kaldırır. Fakat Noddings bu düşünceyi zararlı ve saçma olarak tanımlamaktadır. Diyelim ki bir annenin küçük çocuğuna karşı ilk sorumluluğunun onu besleyici yiyeceklerle beslemek olduğuna karar verdik. Annenin birincil sorumluluğundan dolayı artık çocuğuna nitelikli bir şekilde bakmayacağını; onu gerektiği gibi giydirmeyeceğini düşünmek anlamsız olmaz mıdı $?^{49}$ Ahlaki ideallerin eğitim süreçleri, eğitim kurumları tarafından temel hedef olarak görülmesi bir şeydir; buna bağlı olarak akademik eğitimin ihmal edildiğini söylemek başka bir şeydir. Hiç kuşkusuz birincisinin varlığı ikincisinin varlığını ihlal (veya ihmal) eden bir durum değildir. Öyle ki salt akademik başarıyı hedefleyen okullar, öğrencilerinin yalnızca belirli bir üst kümesine başarılı bir şekilde hizmet ederken geri kalan alt kümeye hizmet etmekte başarısız olurlar. ${ }^{50}$ Eğitim aracılığıyla insanlarda bir etik duyarlılık oluşturmak ve bu tür bir duyarlılığ eğitimin temel amaçlarından biri haline getirmek kaçınılmazdır. Birey bu yolla etik sorunlara karşı duyarlı bir hale gelecek ve ahlaki bir zeminden hareketle sorunları analiz etme imkanına sahip olacaktır.

Eğitim, öğrencilerin farklı kapasitelerini sistematik olarak geliştirmeyi hedeflediği gibi onların ahlaki gelişimlerini de hedeflemektedir. Çünkü insanların akademik anlamda gelişmesi gerektiği gibi ahlaki anlamda da gelişmesi gerekmektedir. Eğitimin hedeflerini kişileri bilişsel anlamda eğitmek ve onları bilgiyle kuşatmak gibi hedeflerle sınırlamak doğru değildir. Eğitim aynı zamanda öğrencinin ahlaki gelişimini de içeren bir süreçtir. O nedenle salt dışsal hedefleri olan bir eğitim yeterli değildir; eğitimin içkin hedefleri de olmak durumundadır. Sözgelimi, Sokrates açısından, insani gelişimin en yüksek aşaması ile 'iyi'nin bilgisini bilmek arasında bir bağ söz konusudur. ${ }^{51} \mathrm{O}$ halde 'insani gelişim' veya ‘insan olma' ile eğitim arasında özsel bir bağlantı vardır. İnsan olmanın genel amaçlarını kavramak, onların farkına varmak için eğitim çok önemli bir değere sahiptir. Çünkü insan olmanın tam olarak neye tekabül ettiği bilinerek ancak insani anlamda gelişmek mümkün olabilir. Buna göre olguların-verilerin öğrenilmesi veya aktarımı olarak tanımlanan bir eğitim anlayışının 'insan olma' kimliğini inşa etmesi imkânsızdır. Nitekim sadece olguların veya verilerin aktarımı ile 'iyi' insan olma arasında doğrusal bir ilişki söz konusu değildir. Bu çerçeveden

49 Nel Noddings, Caring, (Berkeley and Los Angeles, California: University of California Press, 1986), s. 173.

50 Riley, "Moral Identity and Moral Education: A Roycean Proposal for School Choice", s. 98.

51 Thomas Wren, "Philosophical Moorings", Handbook of Moral and Character Education, ed. Larry P. Nucci, Darcia Narvaez, (New York: Routledge, 2008), s. 13. 
bakıldığında eğitimin temel anlamı 'insan olma' kimliğini oluşturmaktır. Bir eğitimci olmak, bütün insanların 'iyi' birer insan olarak yaşamlarını sürdürebilme kapasiteleriyle ilgilenmektir. 'İyi' bir yaşam için kişilerin kendilerini tanımaları/öğrenmeleri veya kendi varoluşsal anlamlarının farkına varmaları zorunludur. ${ }^{52}$

Salt mekanik olarak ortaya çıkan bir eğitim anlayışının birçok kusuru beraberinde taşıması kaçınılmazdır. İnsanın kendi varoluşsal hedefine (misyonuna) kavuşması için eğitimin ahlaki kimliği hedeflemesi gerekir. Çünkü ahlaki kimlik ile 'insan olma' kimliği arasında özsel bir bağlantı vardır. Eğitim süreci böyle bir temele dayanamadığı sürece onun anlamlı bir çabaya dönüşmesi söz konusu olmayacaktır. Eğitim aracılığıyla ahlaki bir kişilik oluşturmak ve bu tür bir duyarlılığı eğitimin temel amaçlarından biri haline getirmek gereklidir. Birey bu yolla ahlaki sorunlara karşı duyarlı bir hale gelecek ve ahlaki ilkelerden hareketle bu sorunları analiz etme imkanına sahip olacaktır. Kant'ın da belirttiği gibi, mevcut eğitim anlayışlarıyla insanın varoluşsal amacına tam olarak ulaşması mümkün değildir. Öncelikli olarak, bireyler insanın varoluşsal amacını dikkate almalı ve özellikle insanlığın gelişimine yönelik bir bilince sahip olmalıdırlar. Bu da bireyin insanlık fikrine ve misyonuna göre eğitilmesi anlamına gelmektedir. Öyle ki insani gelişim sadece yetenekli bireylerin varlığına dayanmaz; aynı zamanda ahlaki bireylerin varlığına da dayanır. Buna göre, okulların yapısı ve misyonu bu gerçekliği içerecek şekilde inşa edilmelidir. İnsan doğasının gerektirdiği hedefe ulaşmak için ‘iyi’ bir dünya fikrine ilgi duyan ve insani açıdan iyileştirilmiş bir gelecek tasavvuruna sahip olan bireylerin varlığı son derece önemlidir. ${ }^{53} \mathrm{O}$ nedenle insanın varoluşsal amacına daha uygun olan bir eğitim planı hazırlamak kaçınılmazdır.

Hiç kuşkusuz eğitim aracılığıyla ahlaki kimlik inşası pedagojik bir tartışmayı gerektirmektedir. Ahlaki değerlerin birey tarafından özümsenmesi ve söz konusu değerlerin bir kimliğe dönüşmesi kritik bir öneme sahiptir. Pekâlâ, ne tür bir yöntem takip etmekte fayda vardır? Verilen eğitimin bireyde ahlaki bir gelişimle sonuçlanması, bireyin bu eğitimden hareketle ahlaki bir kimliğe sahip olması ile takip edilen yöntem arasında sıkı bir ilişki söz konusudur. Nitekim ahlaki kimlik kişinin tek başına başardığı bir şey değildir; aldığ eğitim veya eğitim aldığı öğretmen tarafından derinden şekillenen bir şeydir. Öğrencilerin ahlaki kimliklerinin-kişiliklerinin gelişiminde öğretmenlerin çok büyük sorumlulukları vardır. Öğretmenler öğrencilerin sadece akademik-bilişsel gelişimlerini etkileyenler olarak tanımlanmamalı, aynı zamanda onların ahlaki kimlikleri üzerinde derin ve kalıcı bir etkiye sahip olmalıdır. Peki nasıl?

Kant'a göre, 'sadece' öğretmen olan öğretmen ile 'rehber' olan öğretmen arasında temel bir fark söz konusudur. İlki sadece okul için, ikincisi yaşam için eğitim verir. ${ }^{54}$ Gazali'nin de belirttiği gibi, eğitim sadece öğretmenin öğrencisine bilgi aktarması ve ardından öğretmen ve öğrencinin her birinin kendi ayrı yollarına gittiği bir süreç değildir. Daha ziyade, öğretmene ve öğrenciye eşit derecede etki eden ve fayda sağlayan bir 'etkileşim' sürecidir. Burada öğretmen eğitim vererek, öğrenci de bilgi edinme yoluyla kendini geliştirilerek/yetiştirerek değer kazanır. Onun için, öğretmen yalnızca bir satıcı veya bilgi aracı değil, bir model ve örnek olmalıdır. Öğretmenin görevi belirli bir konunun öğretilmesiyle sınırlı değildir. Aksine onun sorumluluk alanı öğrencinin kişiliğinin ve yaşamının tüm yönlerini kapsamalıdır. Bundan hareketle Gazali, öğretmenler için 'profesyonel etik bir ilke' öneriyor: Öğretmen neyi ögütlüyorsa onu kendi de uygulamalıdır ve özelde öğrencilerine genelde bütün topluma örnek olmalıdır. ${ }^{55}$

Öğrenciler kendileri açısından önemli bir rol model olan öğretmenlerini örnek alarak bir kimlik inşa ederler. Öğrencilerin bu süreçte inşa ettikleri kimliklerinin içeriği ile öğretmenlerinin kimliklerinin içeriği arasında önemli bir etkileşim/benzeşim söz konusudur. Öğrencilerin amaçlanan bir kimliğe sahip olmaları için kendi öğretmenlerinin de böyle bir kimliğe sahip olmaları son derece önemlidir. Bir öğretmenin eğitim anlayışına emanet edilen bir çocuğun ahlaki gelişimi ile öğretmenin bu konudaki tutumu arasında önemli benzerlikler vardır. O halde öğretmenler sadece öğrencilerin bilişsel gelişimlerini ve başarılarını etkileyen-

52 Angus Brook, "What is Education?: Re-reading Metaphysics in Search of Foundations", New Blackfriars, Vol. 94, No. 1049 (2013), s.44-49.

53 Immanuel Kant, "Lectures on Pedagogy", Translated by Robert B. Louden, Anthropology, History, and Education, ed. Gunter Zoller, Robert B. Louden, (Cambridge: Cambridge University Press, 2007), s. 440-444.

54 Kant, "Lectures on Pedagogy", s. 446.

55 Nabil Nofal, "Al-Ghazali", Prospects: the Quarterly Review of Comparative Education, (Paris: International Bureau of Education), vol. XXIII, no. 3/4, (1993), s. 9-11. 
ler olarak tanımlanmamalı, aynı zamanda öğrencilerin ahlaki yaşamları üzerinde derin ve kalıcı bir etkiye sahip kişiler olarak da tanımlanmalıdırlar. ${ }^{56}$ Ahlaki dilin öğrenciye aktarımında öğretmen temel bir statüye sahip olduğu için bu etkileşim sürecinde öğretmenin 'etik konuşmak' yerine 'etik yaşaması' daha etkili olacaktır. Ahlaki kimlik kişinin kendi başına başardığı bir şey değildir; öğretmenler tarafından da derinden şekillendirilen bir şeydir. Pekâlâ, ahlaki kimlik inşası için nasıl bir eğitim?

Eğitim süreçlerinin belli dönemlerinde tekrar, ezber gibi öğrenme biçimleri elbette işe yarayabilir. Fakat ileri aşamalarda esas olan açıklama, anlama ve bilinçli uygulama olmalıdır. Sadece yanlış yapmayı önlemeye dönük bir bakış açısını geliştirmenin yetersiz olduğunu söylemek mümkündür. İyi olanı yapmaya neden olacak bir bakış açısını da kişiye kazandırmak son derece önemlidir. Sadece pasif bir şekilde kurallara itaat etmek veya kuralları düşünmeksizin kabul etmek oldukça mekanik bir bakış açısıdır. ${ }^{57}$ Kaldı ki, iyi olanı yapma isteği, sporda kazanma isteği ile aynı şey değildir. Başkasına yardım etme ihtiyacı, bir testte iyi performans gösterme ihtiyacı ile aynı şey değildir. Bir adalet kuralını sürdürmenin veya sosyal açıdan yoksun bir kişinin sorumluluğunu üstlenmenin koşulları, iyi bilinen bir müzik parçasını dinlemekle aynı değildir. ${ }^{58}$ O nedenle, ahlak eğitimi bu boyutuyla diğer eğitim biçimlerinden oldukça farklıdır. Kişinin ahlak eğitiminde aktif olması veya bunu pratik olarak da ortaya koyması bu farklılığın en önemli nedenidir. Ahlaki bir eylemde bulunan kişi bu eyleminin temelini kavramalı ve bunun bilincinde olmalıdır.

O halde, öğretmenin salt bilgi aktarımı yaparak öğrencide ahlaki bir kimliğin oluşmasına aracı olması beklenemez. Salt teorik bir düzlem temel alınarak bireye ahlaki bir kimlik kazandırılamaz. Yine, bir öğretmenin, sözgelimi, merhamet, adalet, dürüstlük, cömertlik, nezaket, çalışkanlık gibi sıfatlara sahip olmaksızın öğrencilerine 'bu şekilde' davranın talebinde bulunmasının pratik bir karşılığı olmayacaktır. Yaşantı/ deneyim olmaksızın salt bir içerik aktarımı bireylere ahlaki bir kimlik kazandırmaktan son derece uzaktır. Öğretmen salt soyut ahlaki yargılardan hareketle bir ahlaki kimlik kazandırmaya çalışmamalı, bunu yaşantı yoluyla desteklemelidir. Bir idealin motivasyonel gücü soyut olmaktan uzaktır, çünkü idealin önemi, değeri ve güzelliği gerçekten deneyimlenen birçok somut örneğin birikmiş etkileri üzerine aşamalı olarak inşa edilir. Örneğin adalet ideali, adalet kavramını ve çeşitli adalet normlarını öğrenerek ya da adaletle ilgili konuşmalara maruz bırakılarak inşa edilmez. Kişi kendisinde ve başkalarında somut adalet eylemlerinin olumlu sonuçlarını ve somut adaletsizliklerin zarar verici sonuçlarını deneyimleyerek adalet idealini inşa etmektedir. ${ }^{59} \mathrm{O}$ halde öğretmenlerden: (i) Öğrencilere örnek/model olabilmeleri veya onlara liderlik edebilmeleri için kendi ahlaki ve etik karakterlerini geliştirmeleri ve (ii) ahlak ve karakter eğitiminin pedagojisini öğrenmeleri beklenmektedir. ${ }^{60} \mathrm{Bu}$ beklentileri karşılayamayan bir öğretmenin öğrenciye ahlaki bir kimlik kazandırması kolay olmayacaktır.

56 Betty A. Sichel, "Virtue and Character: Moral Languages and Moral Education", The Clearing House, Vol. 64, No. 5, (1991), s. 299.

57 Kant, "Lectures on Pedagogy", s. 446.

58 Karin Heinrichs, Fritz Oser and Terence Lovat (ed), Handbook of Moral Motivation, (Rotterdam: Sense Publishers, 2013), s. 1.

59 Blasi, "Moral Functioning: Moral Understanding and Personality", s. 343.

60 Merle J. Schwartz, "Teacher Education for Moral and Character Education”, Handbook of Moral and Character Education, ed. Larry P. Nucci, Darcia Narvaez, (New York: Routledge, 2008). s. 597. 


\section{SONUÇ}

Hiç kuşkusuz, ahlaki kimlik gelişimini besleyen faktörlerin belirlenmesi zorunludur; bu tür bir bilgi ahlak eğitimi için paha biçilmez olabilir. Bilindiği üzere bilişsel-gelişimsel yaklaşım bilişsel gelişimin ahlaktaki rolüne odaklanan bir teoriyi temel almaktadır. Bu yaklaşımda bilişsel gelişim veya ahlaki muhakeme, ahlaki motivasyonun birincil kaynağı olarak görülmekte; ahlaki yargının doğrudan ahlaki eylemle bağlantılı olduğu iddia edilmektedir. Sözgelimi Kohlberg’e göre, ahlaki davranışta bulunmak bir dereceye kadar hem bilişsel gelişime hem de bakış açısı kazanma becerilerine bağlıdır. Eyleme geçmek için ahlaki motivasyon, kişinin ahlaki ilkelerin kural koyucu doğasına sadakatinden gelir. Dolayısıyla harekete geçmemek bir ilkeye ihanet etmektir. ${ }^{61}$ Fakat insanların doğru olan şeylerin ne olduğunu bildiklerini ancak yanlış olan şeyleri yaptıklarını gözlemlemek şaşırtıcı değildir. Çünkü insanlar bildikleri ve anladıkları şeylerle davranışlarının çelişmesine izin vermektedir. ${ }^{62}$ Peki neden?

Bilişsel yaklaşımların aksine, Blasi ahlaki kimliğin ahlaktaki rolüne odaklanan bir teorinin ana hatlarını çizerek ahlaki yargi-ahlaki eylem sorununu çözmeye çalışmaktadır. Benlik-ahlak bütünleşmesini temel alan bu yaklaşımda ahlaki kimlik, ahlaki motivasyonun birincil kaynağı olarak görülür. Blasi, ahlaki işlevsellik için son derece önemli olan ve ahlaki motivasyonu güçlendiren iki süreçten söz etmektedir. Birincisi iradenin oluşturulması ve yapılandırılması ile ilgilidir. Ikincisi, sonunda öz kimliğe yol açan benlik duygusunun aşamalı inşası ile ilgilidir. Blasi, iradeyi eylem üretiminde etkili olan özel bir istekten (desire) oluşan bir şey olarak tanımlamaktadır. Kişi isteyerek ahlaki istekler gibi belirli arzuları istemekte ve onları kendine mal etmektedir. Kasıtlı bir eylemin belirlenmesinde kişi, başka bir isteğe karşı ahlaki bir isteği sonra da diğerine karşı bir diğerini tercih eder. Kişi, diğer pek çok değerli şeyi önemsemeye devam etse de ahlak için bir endişe edinir, ahlakı önemser. O nedenle, diyor Blasi, bir kişi ahlaki isteklerinin sadece mevcut durumda değil de gelecekte de etkili olmasını isteyecek düzeyde ahlakı önemsiyorsa, o kişi artık ahlaki isteklerini gerçekleştirmekle yükümlüdür, ahlaken sorumludur. Bu açıdan, sorumluluk (ahlaki) iradenin bir biçimi olarak anlaşılmalıdır. ${ }^{63}$

İkincisi ise benlik süreçlerini ahlaki normlara, ilkelere ve değerlere uygun hale getirmekle ilgilidir. Burada kişi kendini geliştirme duygusuna-düşüncesine önem vermekte ve söz konusu ahlaki normlar1-değerleri 'kişi olma' kavramının anlamıyla bütünleştirmektedir. Burada 'kişi' kavramı ahlaki normlar-değerler üzerinden tanımlanmakta ve bunlar kişinin kimliği haline dönüşmektedir. Blasi’ye göre, ahlaklı bir insan olmak veya olmak istemek benlik tasavvuruyla ilgili bir durumdur. Kişinin belirli yönleri benlik duygusu açısından diğerlerinden daha temel olarak kabul edilir. Sonunda, bir 'kişi olma' unsurları olarak kabul edilen çeşitli özellikler hiyerarşik olarak düzenlenir ve benlik duygusu birlik ve derinlik kazanır. Böylece kişi, sahip olduğu birkaç yönünü kendi varlığının merkezi-özü olarak kabul eder. Blasi bunu öz-kimlik (self identity) olarak tanımlamaktadır. Bu insanlar için; (i) kimliğini koruma isteği, (ii) zorunlu olarak kendisini nasıl tasavvur ediyorsa o şekilde var olma isteği ve (iii) tutarlı bir şekilde varlığını-bütünlüğünü koruma isteği ve ihtiyacı gibi önemli istekler ortaya çıkmaktadır. Öyle ki, kişinin kasıtlı olarak kendi temel değerlerine ve taahhütlerine karşıt davranması, aynı zamanda onun kendine ihanet etmesi ve kendi benliğini-kişiliğini yitirmesi şeklinde deneyimlenir. ${ }^{64}$

Açıkça görüldüğü üzere, benlik-ahlak bütünleşmesi ‘(i) kişinin kendisini tanımlamasında ahlaki değerlerin merkezi bir statüye sahip olması ve (ii) kişinin ahlaki değerleri içselleştirme veya kendisiyle bütünleştirme düzeyi gibi iki temel ilkeye bağlıdır. Dolayısıyla, kişinin kimliğinin içeriği açısından ahlaki değerlerin ne tür bir statüye sahip olduğu son derece önemlidir. Burada ahlaki değerlerin kişinin motivasyonel ve duygusal sistemleriyle bütünleşmesi ve söz konusu değerlerin kişinin benlik tasavvuru ile kimliğinin inşasına temel olması gerekmektedir. ${ }^{65}$ Burada sunulan tanıma göre, ahlaki kimlik ve eylem arasındaki motivasyonel itici güç, bir kişinin belirli ahlaki özellikleri kendi benlik kavramı için esas olarak görmesine

61 Bergman, "Why Be Moral? A Conceptual Model from Developmental Psychology”, s. 120.

62 Blasi, "Moral Functioning: Moral Understanding and Personality", s. 341.

63 Blasi, "Moral Functioning: Moral Understanding and Personality", s. 342.

64 Blasi, "Moral Functioning: Moral Understanding and Personality", 343.

65 Krettenauer, Hertz, "What Develops in Moral Identities? A Critical Review”, s. 139. 
bağlıdır. Kişi, ahlaki erdemleri ve değerleri benlik duyguları için ne kadar önemli görürse, ahlaki davranışı sergileme olasılığı o kadar artacaktır. Bu nedenle, benlik ve ahlak arasında bağlantıdan harekete ahlaki motivasyon kişinin ahlaki kimliğinin bir sonucudur ve harekete geçmemek kendine ihanet etmektir. ${ }^{66}$ Ahlaki kavrayış ahlaki eyleme yönlendirmeye yardımcı olsa da eyleme götüren motive edici kıvılcımı sağlayan şey kimliktir.

Pekâlâ, ilkelere sadakat mı, kişinin kendisine sadakati mı? Yoksa, ahlaki eylemin motive edici gücü olarak ahlaki kimlik ve ahlaki yargı birlikteliği mi?

Kendine sadakatin soyut bir ilkeye sadakatten çok daha büyük bir motivasyon potansiyeline sahip olduğunu söylemek mümkündür. Ancak, ahlaki motivasyon ve eylem için benlik veya kimliğin öneminden söz etmek bir şeydir; ahlaki yargının değerini dikkate almamak başka bir şeydir. Elbette Blasi'nin ahlaki motivasyon ve eylem için benlik veya kimliğin önemi konusundaki anlayışımızı geliştirmesi değerlidir. Fakat bu durum ahlaki yargının rolünü küçümseme pahasına yapılıyorsa sorunludur. ${ }^{67} \mathrm{O}$ halde ahlaki bir kimliğe sahip olmak için ahlaki akıl yürütme zorunludur. Ahlaki bir akıl yürütmenin olmadığ bir bireyde ahlaki bir kimliğin (bir iç tutarlılık içerecek şekilde) inşası da kolay olmayacaktır. Ahlaki akıl yürütme doğal olarak bilişsel bir kavrayışı gerektirmektedir ve ahlaki kavrayışın kişilik süreçleriyle kesiştiği çok rahatlıkla söylenebilir. ${ }^{68}$ Ahlaki kimlik ahlaki eylem için çok önemli olsa da ahlaki kavrayışın motive edici gücü ile birleştiğinde daha fazla motivasyon ve bağlılık sağlayacaktır. O nedenle ahlaki işleyişe yönelik tekçi yaklaşımlardan ziyade daha bütüncül görüşlere yönelmek kaçınılmazdır. Bu da ahlaki ahlaki benlik, ahlaki kimlik, ahlaki kavrayış ve ahlaki davranış gibi kişiliğin farklı yönleri arasında bütünsel bir bakış açısına sahip olmayı gerektirmektedir. -

66 Bergman, "Why Be Moral? A Conceptual Model from Developmental Psychology", s. 120.

67 Bergman, "Why Be Moral? A Conceptual Model from Developmental Psychology", s. 120.

68 Bkz. Narvaez, Lapsley, ed., Personality, Identity, and Character, s. 1. 


\section{KAYNAKÇA}

Aiken, Henry David, “Moral Reasoning”, Ethics, Vol. 64, No. 1 (1953).

Aquino, Karl, “The Self-Importance of Moral Identity”, Journal of Personality and Social Psychology, Vol. 83, No. 6, (2002).

Bergman, Roger, "Why Be Moral? A Conceptual Model from Developmental Psychology”, Human Development, (2002).

Brook, Angus, "What is Education?: Re-reading Metaphysics in Search of Foundations", New Blackfriars, Vol. 94, No. 1049 (2013).

Carr, David, "Character Education as the Cultivation of Virtue", Handbook of Moral and Character Education, ed. Larry P. Nucci, Darcia Narvaez, (New York: Routledge, 2008).

Duska, Ronald, Whelan, Mariellen, Moral Development: A Guide to Piaget and Kohlberg, ed. Ronald Duska and Mariellen Whelan, (New York, Paramus, Toronto: Paulist Press, 1975).

Hardy, Sam A., Carlo, Gustavo, "Identity as a Source of Moral Motivation”, Human ～Development 48, (2005).

"Moral Identity: What Is It, How Does It Develop, and Is It Linked to Moral Action?", Child Development Perspectives, Volume 5, Number 3, (2011).

Heinrichs, Karin, Oser, Fritz Oser, Lovat, Terence, (ed), Handbook of Moral Motivation, (Rotterdam: Sense Publishers, 2013).

Kant, Immanuel, "Lectures on Pedagogy", Translated by Robert B. Louden, Anthropology, History, and Education, ed. Gunter Zoller, Robert B. Louden, (Cambridge: Cambridge University Press, 2007).

Krettenauer, Tobias, Hertz, Steven, "What Develops in Moral Identities? A Critical Review”, Human Development, Vol. 58, No. 3 (2015).

Lapsley, Daniel K., "Moral Self-Identity as the Aim of Education”, Handbook of Moral and Character Education, ed. Larry P. Nucci, Darcia Narvaez, (New York: Routledge, 2008),

Lapsley, Daniel K., Narvaez, Narvaez, Moral Development, Self, and Identity, ed. Daniel K. Lapsley and Darcia Narvaez, (London: Lawrence Erlbaum Associates, 2004).

Narvaez, Darcia, "Neurobiology and Moral Mindset”, Handbook of Moral Motivation, (ed), Karin Heinrichs, Fritz Oser and Terence Lovat , (Rotterdam: Sense Publishers, 2013).

Narvaez, Darcia, Lapsley, Daniel K. Personality, Identity, and Character, ed. Darcia Narvaez and Daniel K. Lapsley, (New York : Cambridge University Press, 2009).

Noddings, Nel, Caring, (Berkeley and Los Angeles, California: University of California Press, 1986).

Nofal, Nabil, "Al-Ghazali”, Prospects: the Quarterly Review of Comparative Education, (Paris: International Bureau of Education), vol. XXIII, no. 3/4, (1993).

Norman, Richard, The Moral Philosophers, (Oxford: Oxford University Press, 1998).

Riley, Sean, "Moral Identity and Moral Education: A Roycean Proposal for School Choice”, The Pluralist, Vol. 2, No. 2 (2007).

Schlenker, Barry R., Miller, Marisa L., Johnson, Ryan M., "Moral Identity, Integrity, and Personal Responsibility", Personality, Identity, and Character, ed. Darcia Narvaez and Daniel K. Lapsley, (New York : Cambridge University Press, 2009).

Schwartz, Merle J. "Teacher Education for Moral and Character Education”, Handbook of Moral and Character Education, ed. Larry P. Nucci, Darcia Narvaez, (New York: Routledge, 2008).

Sichel, Betty A., "Virtue and Character: Moral Languages and Moral Education", The Clearing House, Vol. 64, No. 5, (1991).

Spiecker, Ben, Steutel, Jan, "Moral Identity and Education in a Multicultural Society", Studies in Philosophy and Education 15: 159-165, (1996).

Stets, Jan E., Carter, Michael J., “The Moral Self: Applying Identity Theory”, Social Psychology Quarterly, Vol. 74, No. 2, (2011).

Taylor, Charles, Sources of the Self: The Making of the Modern Identity, Harvard University Press, 1989).

Thoma, Stephen J., Muriel J. Bebeau "Moral Motivation and the Four Component Model”, Handbook of Moral Motivation, (Rotterdam: Sense Publishers, 2013).

Wren, Thomas, "Philosophical Moorings", Handbook of Moral and Character Education, ed. Larry P. Nucci, Darcia Narvaez, (New York: Routledge, 2008).

Xu, Zhi Xing, Ma, Hing Keung, "How Can a Deontological Decision Lead to Moral Behavior? The Moderating Role of Moral Identity", Journal of Business Ethics, September 2016, Vol. 137, No. 3 (2016). 


\section{EXTENDED ABSTRACT}

What is the source of the motivation that generates moral action? It is possible to say that there are different approaches to this issue. According to the cognitive developmental approach, there is an essential connection between moral judgment and moral action. As a matter of fact, since moral judgments have a rule-making nature, they require an obligation to act. For example, Kohlberg hypothesizes that if moral principles are understood, they will motivate moral actions. Therefore, the motivation to act is associated with an individual's moral insight or moral reasoning. Of course, this approach reflects the principle of 'to do good, it is necessary to know good'. Philosophers like Socrates and Plato thought that 'to know the good is to do the good; to do the good, one must know the good'. For Socrates, there is a connection between the highest stage of human development and knowing the knowledge of the 'good'. In terms of this approach, moral knowledge is essential for a moral life. When people know what they have to do, they rationally do nothing else. From this perspective, the only reason for wrongdoing is expressed as ignorance. Is it really that simple? Can moral judgment or moral reasoning be considered the ultimate criterion for moral action?

Moral maturity requires not only having the knowledge of right (or wrong), but also acting in accordance with this right knowledge. What needs to be achieved here is to think right and act right. But there are countless examples of people differing in the way they transform their moral judgments into action. Most people think of themselves as principled and often also believe that they act consistently with their principles. But consistency is a fundamental motive that can only be satisfied by the harmony between judgment and action. Most of the time, situations encountered in life can discourage a person from his moral principles. Here it is the strength of personal commitment to moral principles that determines the strength of the relationship between moral judgment and moral action. Personal commitment binds the self to moral principles and causes an obligation to act in a way that is consistent with these principles. These people, whose selves are composed of moral values and principles, feel responsible for their actions and actively strive for harmony between judgment and action.

Such individuals, who have a strong internal moral motivation, do not need an immoral internal motivation such as self-interest to act according to their moral judgments, and they do not need an external motivation such as social approval or disapproval. As these individuals are reluctant to condone ethical failures-violations, they are also reluctant to rationalize these ethical failures-violations. Moral principles have a trans-situational nature. For this, in terms of a self integrated with morality, the existence of moral principles and their guiding action is a fundamental approach. It is the application of principles, regardless of personal consequences or self-serving rationalizations. An unconditional commitment to principles is a fundamental attribute of one's identity. A high level of personal commitment and a principled attitude becomes the dominant schema for interpreting events and guiding behavior. Therefore, according to Augusto Blasi, moral judgment or reasoning processes are necessary in moral functioning, but they are not sufficient for action. There is a gap between judgment and action; moral identity has the power to fill this gap between moral judgment and moral action.

Blasi presents an approach on how to bridge the gap between judgment and action in the moral development process. In this literature, different concepts such as moral person, moral personality, moral self and moral identity are used to denote personality-moral integration; and concepts such as personality, self, identity are examined in terms of morality. Here, the concept of 'person' is defined through moral norms-values and these become the identity of the person. In this understanding, which aims to integrate moral understanding with moral personality, self-identity has a basic explanatory status in moral functioning. Because of the centrality of moral values in one's self/identity, the self is seen as an important determinant of moral behavior. Since moral beliefs and values are integrated/processed into personality and one's sense of self, moral goals and personal goals of the individual are fully integrated. Here, there is a linear connection between the emergence of moral behavior and the integration of moral beliefs-values into (one's) personality and sense of self. Therefore, according to Blasi, only a self/identity characterized by moral concepts can bridge the gap between judgment and action. Therefore, the self constructed from moral references is here accepted as an important determinant of moral action. 